\title{
CHURCH AND STATE IN NORTH AMERICA
}

\author{
HERBERT A. SMITH
}

Cavour's great principle of libera chiesa in libeio stato-"a free church in a free state" - has proved easier to enunciate in theory than to realise in practice, and the difficulty has been as great in the new world as in the old. The early days of Eurupean settlement upon the American continent witnessed a wide variety of experiments, ranging from the generous toleration of Maryland and Pennsylvania to the namow Puritan theocracies of New England, and the close co-operation in New France of a church and a state with an identical membership. In our own time we have seen an abundance of constitutional controversies over such questions as the reading of the Bible in public schools, and the much advertised "Anti-Evolution Law" of Tennessee is an example of an attempt to incorporate certain dogmatic religious views into the legal structure of the state. No modern state, however secularized, can entirely ignore religion. So long as churches exist they must be accepted as facts of which the law must take account, and the problem for the state is to determine its relation towards thern.

When the Privy Council delivered its long deferred decision in the case of Despatie $v$. Tremblay ${ }^{1}$ it closed one of these controversies and demolished a peculiar theory of church and state which had been gradually gaining strength in the Province of Quebec for more than a hundred years. Briefly stated, the theory came to this-that the canon law of the Roman Church, as defined by her ecclesiastical courts, was binding upon all Roman Catholics in the Province as part of the civil law to be enforced by civil tribunals, and was also binding upon citizens of other faiths in so far as the relationship of marriage united them to persons of the Roman Catholic religion. In other words, there was to be one marriage law for Roman Catholies and another for Protestants." The former was to be interpreted by the ecclesiastical courts, and then to be enforced by the civil machinery in all cases where either or both of the parties were Roman Catholic. ${ }^{3}$

\footnotetext{
1 (1921) L. R. 1 A. C. 702.

2 The word "Protestant" is used as a convenient negative deseription of all who are not Roman Catholies, and without any further doctrinal significance.

" It should in fairness be added that this theory was nominally applicable to all religious denominations alike, but in practice difficulties only arose in connection with members of the Roman Catholic Chureh.
} 
As a proposition of law this formidable theory was built upon the somewhat slender foundation of a single article in the Civil Code, enacted by the legislature of the old Province of Canada in 1866. The title of the code dealing with marriage begins by enumerating ${ }^{4}$ various familiar impediments to marriage, such as age, impotency, lack of parental consent, and relationship within certain degrees, the list of prohibited degrees being the same as that of the contemporary English law. Then follows Article 127; in these words: "The other impediments recognised according to the different religious persuasions, as resulting from relationship or affinity or from other causes, remain subject to the rules hitherto followed in the different churches and religious communities. The right, likewise, of granting dispensations from such impediments appertains, as heretofore, to those who have hitherto enjoyed it." Article 129 exempts the clergy from the obligation of celebrating marriages which would violate the rules of their respective churches.

The codification of the law upon acutely disputed questions is often a thorny matter, and this is clearly one of the cases in which codifiers have refused to codify. No new law is propounded, and no old problems are resolved. Whatever the law was, so it remains, and the elucidation of its meaning is left to the courts. The solution of the difficulty must therefore be found somewhere in the history of Quebec.

It was common ground between the parties that before the cession of Canada the Roman canon law relating to marriage was accepted as part of the French civil law and administered as such by the civil courts. The canon law included, among other things, a table of prohibited degrees which extended so far as to annul a marriage between fourth cousins, unless the parties had obtained a dispensation from their bishop. In practice this incorporation of the canonical rules into the civil law created no difficulty, since Canada was a country of one religion only, the immigration of Huguenots having been forbidden by the French charter of 1627 . No other worship was tolerated, and the maxriage of Protestants within Canada before the cession would have been a legal impossibility. Clearly this could not continue to be the law after Canada had become a British colony and a considerable number of Protestants had settled in the country under the protection of the British flag. One of two things must then

\footnotetext{
* Civil Code of Quebec, articles 115-126.

- It should be noted that in France a procedure known as the appol comme d'abus, corresponding to the English writs of prohibition and cortiorari, enabled the secular courts to confine the church strictly within their proper limits. No secular lawyers were allowed in Canada under the French régime, and the absence of an educated opinion among tho French laity doubtless encouraged the subsequent extreme assertion of the ecclesiastical claims.
} 
have happened. Either the English marriage law of $1540^{3}$ had been introduced by the fact of cession as the law uniformly applicable to the whole country, or else there was one marriage law for the old French population and another for the new settlers, cases of mixed marriages being governed by the canon law. In order to resolve this question we must consider, in order, such historical documents as are relevant.

The first in point of time are the military articles of capitulation drawn up for the surrender of Quebec in 1759 and of MIontreal in 1760. For the present it will suffice to consider Articles 27,30 and 31 of the capitulation of MIontreal, which are in the following terms:

27-French Request: "The free exercise of the Catholic, Apostolic, and Roman religion shall subsist entire, in such manner that all the states and the people of the towns and countries, places, and distant posts shall continue to assemble in the churches, and to frequent the sacraments as heretofore, without being molested in any manner, directly or indirectly. These people shall be obliged by the English government to pay their priests the tithes and all the taxes they were used to pay under the government of His iIost Christian Miajesty."

British Reply: "Granted, as to the free exercise of their religion; the obligation of paying the tithes to the priests will depend on the King's pleasure."

30-French Request: "If, by the treaty of peace, Canada should remain in the power of His Britannic Miajesty, His Most Christian Majesty shall continue to name the Bishop of the colony, who shall always be of the Roman communion, and under whose authority the people shall exercise the Roman religion."

British Reply: "Refused."

31-French Request: "The Bishop shall, in case of need, establish new parishes, and provide for the rebuilding of his Cathedral and his Episcopal palace; and, in the meantime, he shall have the liberty to dwell in the towns or parishes, as he shall judge proper. He shall be at liberty to visit his Diocese with the ordinary ceremonies, and exercise all the jurisdiction which his predecessor exercised under the French dominion, save that an oath of fidelity, or a promise to do nothing contrary to His Britannic MIajesty's service, may be required of him."

British Reply: "This article is comprised under the foregoing."

Next comes the treaty of Paris, which was a tripartite agreement signed by Great Britain, France and Spain in 1763 in order to provide for the permanent disposal of their respective possessions in North America and the West Indies. In this treaty the important words are those of Article IV:-

"His Britannic Mlajesty, on his side, agrees to grant the liberty

${ }^{6}$ (1540) 32 Hen. VIII, c. 38. 
of the Catholic religion to the inhabitants of Canada: he will, in consequence, give the most precise and effectual orders, that his new Roman Catholic subjects may profess the worship of their religion according to the rites of the Romish church, as far as the laws of Great Britain permit."

Stopping there for a moment, one or two points call for notice. In the first place, the guarantee of religious liberty is in substantially the same words as those used in the Treaty of Utrecht in 1713, whereby France surrendered to Great Britain the greater part of the present Province of Nova Scotia. Secondly, the words used with regard to Canada in Article IV of the Treaty of Paris are verbally identical with those used in Article XX of the same Treaty providing for the cession of Florida by Spain. The obligation of Article XX descended in the course of the next twenty years to the United States; but neither in Nova Scotia nor in Florida have any claims been put forward on behalf of the Church similar to those maintained in Quebec.

According to English constitutional law the Crown is competent to legislate by proclamation for newly acquired territory until a local legislature is established; and the ratification of the Treaty was quickly followed by a royal proclamation ${ }^{7}$ which defined the limits of the new American possessions and formed the legal basis for the first civil government of Canada as part of the British Empire. The proclamation stated that as soon as possible local legislatures would be set up with power to legislate "as near as may be agreeable to the laws of England, and under such regulations and restrictions as are used in other Colonies." In the meantime courts were to be established "for" hearing and determining all causes, as well criminal as civil, according to law and equity, and as near as may be agreeable to the laws of England," with the usual right of appeal to the Privy Council. Clearly it was intended that Quebec, like most other colonies, should be governed by the principles of the English common law.

In the next year a system of civil government was actually set up in Canada, and General Murray was appointed as the first civil governor of the new colony. In the royal instructions ${ }^{8}$ transmitted to him, the attention of the Governor was called to the provisions of the Treaty of Paris and he was bidden (paragraph 28) to "conform with great exactness to the stipulations of the said Treaty in this respect." At the same time he was warned not to go too far. "You are not", he was told (paragraph 32) "to admit of any ecclesiastical jurisdiction of the See of Rome, or any other foreign ecclesiastical jurisdiction whatsoever in the Province under your government." He was further urged to do

' Kennedy, Documents of the Canadian Constitution, 18-21.

8 Ibid. at 27. 
all he could "to the end that the Church of England may be established both in principles and practice, and that the said inhabitants may by degrees be induced to embrace the Protestant religion." Therefore provision was to be made for Anglican clergy, churches and services, and "you are to take especial care, that a Table of Marriages, established by the Canons of the Church of England, be hung up in all places of public worship, according to the rites of the Church of England," (paragraph 39).

Murray was a warm friend of the French Canadians, and went considerably beyond the letter of his instructions in the tolerance which he accorded to their religion and their laws. He even pressed the home government to permit the establishment of a Roman Catholic bishop at Quebec; and in $1766 \mathrm{MIgr}$ Briand was privately consecrated in France and a tacit consent was given to his quiet assumption of episcopal jurisdiction in Canada. Shortly afterwards Mirray returned to England, and was succeeded by Sir Guy Carleton-afterwards Lord Dorchester-the real author of the Quebec Act of 1774 .

The clouds were now gathering which were shortly to break in the American revolution; and the whole of Carleton's policy as governor was directed towards meeting the coming danger. Like iIurray, he had more sympathy for the quiet French peasants than for the rather troublesome community of English traders who had followed the flag into Canada. In the English he saw potential allies of the rebel colonists; and his only hope of saving Canada for the Crown lay in convincing the French Canadians that in the support of Great Britain alone could they find any security for the maintenance of their religion and their institutions. After some years of steady pressure he obtained the passage of the Quebec Act of $1774,{ }^{\circ}$ though only in the teeth of a vigorous opposition in the British Parliament, where the Act was bitterly denounced as an "establishment of Popery." With incredible stupidity the Continental Congress took up this argument, and pointed to the Quebec Act as yet another example of the wickedness of the British government. Naturally this extinguished any hopes which they may ever have cherished of winning the support of Canada for their cause.

The so-called "establishment of Popery" is to be found in seetion 5 of the Act: ${ }^{10}$

"And, for the more perfect security and ease of the minds of the inhabitants of the said province, it is hereby declared, That His Majesty's subjects, professing the religion of the church of Rome of and in the said province of Quebec, may have, hold, and enjoy the free exercise of the religion of the church of Rome,

${ }^{9}$ (1774) 14 Geo. III, c. 83.

10 Ibid. sec. 5. 
subject to the King's supremacy, declared and established by an act, made in the first year of the reign of Queen Elizabeth, over all the dominions and countries which then did, or thereafter should belong, to the imperial crown of this realm; and that the clergy of the said church may hold, receive, and enjoy, their accustomed dues and rights, with respect to such persons only as shall profess the said religion."

It will be observed that by the last words of this section the payment of church dues is made a civil debt enforceable by legal process against all persons professing the Roman Catholic faith. By this provision, unique at the present day in the laws of this continent, the Roman Church is indeed placed in a privileged position, and to this extent may fairly be said to be "established". On the other hand, it should be noticed that the free exercise of the right of religious worship is made subject to the Elizabethan Act of Supremacy, ${ }^{11}$ which in very comprehensive language expressly prohibits any "jurisdiction" by the See of Rome, or any other foreign power, in any part of the British dominions.

The only other words in the Quebec Act relevant to the present question are those in section 8, which say, "that in all matters of controversy, relative to property and civil rights, resort shall be had to the laws of Canada, as the rule for the decision of the same", subject to any changes that might be introduced by later legislation. The words "property and civil rights" are clearly used in contrast to the later provision in section 11 by which the English criminal law is continued in force.

It is important to observe that the establishment of the French civil law in Quebec rests upon the Quebec Act alone, and not upon anything which took place earlier. Nothing is said about this point in the military capitulations or in the Treaty of Paris; and the royal proclamation of $1763,{ }^{12}$ which set up the first civil government in 1764, authorized the governor to establish courts "for hearing and determining all causes, as well criminal as civil, according to law and equity, and as near as may be agreeable to the laws of England." The instructions to Murray directed him, in setting up such courts, to follow the precedents of other colonies, particularly Nova Scotia. Under this authority Murray duly constituted courts of King's Bench and Common Pleas, in both of which the rules of English law and equity were to be administered. In the court of Common Pleas he enacted that the French law should be administered in all cases "between the natives of this Province", if the cause of action arose before October 1st, 1764. It is clear, therefore, that from 1764 to 1774 the civil law of the Province was English law, and that the Custom of Paris was not continued, but only re-introduced by the words used in section 8 of the Quebec Act.

11 (1558) 1 Eliz. c. 1.

12 Kennedy, supra note 7 , at 18. 
Except for certain statutes dealing with the keeping of marriage registers by the various churches, there is no further legislation upon the subject of marriage until the enactment of the Civil Code in 1866. The claim that Article 127 of the Code incorporates the canon law therefore rests upon two grounds only - the grant of religious freedom in section 5 of the Quebec Act, and the re-establishment of the French law "relative to property and civil rights" in section 8 . The statute of $1540,{ }^{13}$ establishing the English law of prohibited degrees and abolishing most of the purely ecclesiastical impediments to marriage, is expressly stated to apply "in this the King's realm, or any His Grace's other lands and dominions", and it was clearly introduced into Canada by the proclamation of 1763 . Is it repealed by the words "relative to property and civil rights"?

It may seem strange that a question vitally affecting so many people was not finally settled until the Privy Council decided Despatie v. Tremblay in 1921." What is even more surprising is the gradual acceptance in the Province of the ecclesiastical claim that the canon law was part of the civil law to the extent that it could even be enforced, in certain cases, against people who were not of the Roman allegiance. Further, it should be noticed that the extreme ecclesiastical view implied the acceptance, not only of the Roman canon law as it stood in 1763 or 1866, but of any subsequent additions and modifications. In other words, it involved this consequence, that the Pope was a legislature capable of altering the civil law in Canada. The effect of this was not fully realized until the promulgation of the famous Papal decree Ne Temere in 1908. By this decree it was laid down that all marriages between Catholics and non-Catholics were invalid unless celebrated by a Roman Catholic priest under the authority of the bishop, and in a country where this practice was specially permitted.

In strictly ecclesiastical circles it was undoubtedly held that this piece of Papal legislation was automatically incorporated into the law of Quebec under the terms of Article 127. Among civil lawyers there was some difference of opinion, the more conservative, even among those who supported the church claims, holding that the only part of the canon law incorporated was that in force in 1866. I have been able to find only two reported decisions bearing upon this point. In an undefended case, Barbeau v. Dahlmann, ${ }^{15}$ Bruneau, J., annulled a mixed marriage at the petition of the Protestant wife on the ground of non-compliance with the canon law, which in this case must have meant the

\footnotetext{
${ }^{13}$ Supra note 6.

14 Supra note 1.

16 (1920) 59 Que. Super. Ct. 384.
} 
Ne Temere decree. In a more recent case of Plante $v . Z$ annis ${ }^{10}$ the Roman Catholic wife claimed annulment of a marriage contracted with a man of the Greek Orthodox faith and celebrated before a priest of the Anglican communion. Belleau, J., stated that he was reluctantly compelled to follow the Privy Council decision, ${ }^{1 \pi}$ which he described as a "thunderbolt in a clear sky" ("la foudre dans un ciel serein"), but intimated that if he had been free to follow his own judgment, he would have applied the Ne Temere decree ("devenu loi générale le 19 avril 1908") and would have annulled the marriage. It is clear that in the view of the learned judge nothing but the decision of the Privy Council prevented the Pope from being a legislative authority conpetent by his own direct action to alter the civil law of the Province of Quebec. The judgment concludes with an impassioned appeal to the legislature to alter the law in such a manner as to effect this result. ${ }^{18}$

Perhaps the sky was not quite so clear as the learned judge seems to have thought. If conflicting decisions are any guide we can only say that the law was in a state of great uncertainty and confusion, although the main current of authority appeared to favor the ecclesiastical claims. Perhaps the most extreme instance of this point of view is to be found in the early case of Lussier v. Ar'chambault, ${ }^{19}$ decided by the Court of Queen's Bench in 1848. This was a petition for nullity on the ground of impotence, both the parties being Roman Catholics. The court, which included two English-speaking judges, actually declared itself to be incompetent to adjudicate upon the issue until the facts had been found and a decree of nullity pronounced by the episcopal tribunal. This decision was followed in a large number of cases, most of which dealt with the canon law table of prohibited degrees. On the other hand, in Hébert $v$. Clouâtre, Charbonneau, J., refused to annul a mixed marriage celebrated before a Protestant minister, taking the ground that the $\mathrm{Ne} \mathrm{Te}$ mere decree was effective only to bind the consciences of the faithful. To the same effect are Burn $v$. Fontaine, ${ }^{21}$ decided by Torrance, J. in 1872, Delpit v. Côté,22 decided by Archibald, J., in 1901, and the dissenting judgment of Archibald, J., in Trem-

\footnotetext{
16 (1925) 63 Que. Super. Ct. 155.

1i Despatie v. Tremblay, supra note 1.

${ }^{18}$ Since confederation any such law would almost certainly bo boyond the competence of the provincial legislature.

19 (1848) 11 Lower Canada Jurist, 53.

20 (1912) 41 Que. Super. Ct. 249.

21 (1872) 4 Revue Légale, 163.

22 (1901) 20 Que. Super. Ct. 338.
} 
blay $v$. Despatie. ${ }^{*}$ In certain other cases the complications of fact prevented the issue from being clearly raised."

It now remains to state briefly the main features of the celebrated case which closed the controversy from a legal point of view. The parties, both of whom were Roman Catholics, were married in 1904 by their own parish priest, all the civil law requirements as to form having been duly observed, but no ecclesiastical dispensation being obtained, or its necessity foreseen. Six years later the husband discovered that he and his wife were fourth cousins, being descended from common ancestors who had inter-married in 1781, the relationship thus being within the last limit of the prohibited degrees established by the Fourth Council of the Lateran in 1215. Armed with this genealogical evidence he went before the Bishop of St. Hyacinthe and obtained a decree purporting to annul his marriage on the canonical grounds. With the episcopal decree in his hand he next went before the Superior Court, and in 1911 Bruneau, J., gave judgment ${ }^{23}$ annulling the marriage from the point of view of the civil law. "Virtuellement", observed the learned judge, "l'article 127 subordonne le mariage, comme contrat civil, à l'autorité du pouvoir ecclésiastique, puisque le pouvoir séculier ne reconnaît de mariage validement contracté que celui qui l'a été d'après les règles admises par les autorités religieuses, de quelques dénominations qu'elles soient." 26 The acceptance of the theory thus concisely stated would have made of Quebec a jurisdiction unique upon this continent and very nearly unique in the civilised world of to-day.

Upon appeal, this judgment was confirmed ${ }^{2:}$ by a majority of the Court of Review (Tellier and De Lorimier, JJ.), Archibald, $J$, dissenting. From this decision an appeal was taken to the Privy Council, where the case was twice argued, the final hearing being taken in 1920 before Lords Birkenhead, Haldane, Cave, Dunedin, and Moulton-a very strong court. On the 11th of February, 1921, Lord Moulton delivered the judgment of their Lordships allowing the appeal and pronouncing for the validity of the marriage.2s

23 (1912) 43 Que. Super. Ct. 59, 90.

24 In 1912 the Supreme Court of Canada rendered an advisory opinion upon the question, the majority of judges taling the view that the canon law was not incorporated. Iratter of Authority of Parliament of Canades to amend "The Marriage Act" (1912) 46 Can. Sup. Ct. Rep. 132. Upon appeal to the Privy Council it became unnecessary to decide the point.

${ }_{25}$ Tremblay v. Despatie (1911) 40 Que. Super. Ct. 429. In preliminary proceedings in 1910, which are sufficiently indicated in the judgment, the Court of Review held that the trial judge must require proof of the facts instead of merely acting upon the bishop's decree.

${ }^{20}$ Supra note 25 , at 437 .

${ }^{2 \pi}$ Tremblay v. Despatie (1912) 43 Que. Super. Ct. 59.

${ }^{2 s}$ Despatie v. Tremblay, supra note 1. 
Owing to the peculiar conditions obtaining in the Province of Quebec, there is a local tendency to represent the question at issue as being one between Roman Catholic and Protestant, an attitude which unfortunately is likely to make difficult the judicial and dispassionate investigation of the problem involved. In truth the whole dispute is part of the age-long controversy between Church and State, a struggle which has sometimes been keenest when both contending parties were of the same religious faith. This ancient war has been waged on many fronts, of which marriage and education have perhaps been the most important in modern times. So far as education is concerned, the claims of the Church in this Province have been conceded in their entirety in a manner that is unparalleled upon this continent. For educational purposes the whole population of Quebec is crudely divided into two sections, respectively labelled "Catholic" and "Protestant", and the education of Roman Catholics, from the primary schools to the two French universities, is placed under the entire control of the Church. This solution of the educational problem has naturally given rise to many difficulties and inconveniences, but the limits of the present article do not permit of their analysis in detail. At times the war has spread to other fronts; and the claim has even been seriously made that Roman Catholic electors are bound as a matter of conscience and discipline to vote in accordance with the instructions of their clergy. At the general election of 1896 when Mr. Wilfrid Laurier, then the Liberal leader, differed from the hierarchy of his own Church upon the Manitoba schools question, some of the bishops formally asserted that it was mortal sin to vote contrary to clerical instructions, and this attitude was very widely taken up by the parochial clergy. In this case, however, the Holy See itself tactfully discouraged the extreme ecclesiastical claims; and Laurier's victory at the elections served as a salutary warning against the undue assertion of spiritual authority. In one form or another the question is always with us.

A well known epigram has described Oxford as "the home of lost causes and impossible loyalties." The author was not an Oxford man, and to those who know her well the Oxford of our own day appears rather as a place where the newest and headiest wines are continually fermenting in old bottles. With more truth the classic epigram might be applied to the continent of North America, which is more and more tending to become a museum of political and ecclesiastical ideas that have been discarded in Europe. To take one example, the American Constitution is now, both in form and in substance, the oldest constitution of major importance in the civilised world, and has alone succeeded in preserving the independent personal monarchy as a fundamental political institution. To a large extent the political ideas of the eighteenth century are still dominant in the 
United States, and an American politician still finds it possible to arouse popular audiences by references to Washington and George III, whereas his English counterpart would find it about as easy to interest them in Julius Caesar and Boadicea.

So it is with the great problem which has formed the main theme of the present article. Throughout the United States and Canada the official "establishment" of churches and their endowment out of the public funds is forbidden either by positive law or by accepted constitutional practice. But the disappearance of established churches is only one step, and a very minor one, towards the solution of the great question of "a free church in a free state." In Great Britain and in the greater part of Western Europe this controversy has in our own time practically dièd down, not so much by the enactment of legal measures as by the tacit and mutual recognition on both sides of the proper frontiers between them. West of the Atlantic these frontiers are still ill-defined, because America, while outstripping Europe in the acquisition of wealth and the perfection of physical comfort, lags behind her in the diffusion of ideas. For the purposes of this article I have isolated and separately examined a particular controversy which has aroused intense interest in the Province of Quebec; but this isolation is purely artificial, and the real struggle is spread over the whole continent. It would be easy to multiply examples, but one prominent instance may be found in the Puritan legislation upon moral questions, often extreme to the point of absurdity, which is freely scattered over the statute books of the United States. In a large number of cases, such as many of the Sunday observance acts, these statutes represent an effort on the part of the state to enforce by criminal process the spiritual discipline which various religious bodies impose upon their members. IITediaeval witers would have described this procedure as delivering the offenders to "the secular arm." The actual enactment of this type of legislation is usually obtained by pressure exerted. on the part of certain ecclesiastical groups. Miany other statutes designed for such purposes as to enforce sexual morality or to interfere with various amusements are similarly enacted at clerical instigation, and indicate an inability to understand the distinction between the functions of the church as a teacher of morality and the functions of the state as a guardian of public order. Of the attempt of Tennessee to incorporate certain dogmatic beliefs into the educational law of that state the world has perhaps heard enough.=9 For the present all I wish to point out is that there is an essential spiritual kinship between these various groups and the Quebec hierarchy whose claims to control the marriage law I have endeavored to discuss.

\footnotetext{
29 See Waller, The Constitutionality of the Tennessce Anti-Evolution Act (1925) 35 Yate Law Journat, 191.
} 